InOdia $\quad \begin{aligned} & \text { InMedia } \\ & \text { The French Journal of Media Studies }\end{aligned}$

6 | 2017

Fields of Dreams and Messages

Christopher Chávez, Reinventing the Latino Television Viewer: Language, Ideology, and Practice

Lanham: Lexington Books, 2015, 180 pages

Emilie Cheyroux

CpenEdition

Journals

Electronic version

URL: http://journals.openedition.org/inmedia/895

DOI: 10.4000/inmedia.895

ISSN: 2259-4728

Publisher

Center for Research on the English-Speaking World (CREW)

Electronic reference

Emilie Cheyroux, « Christopher Chávez, Reinventing the Latino Television Viewer: Language, Ideology, and Practice », InMedia [Online], 6 | 2017, Online since 18 December 2017, connection on 24 September 2020. URL : http://journals.openedition.org/inmedia/895; DOI : https://doi.org/10.4000/inmedia.895

This text was automatically generated on 24 September 2020

(c) InMedia 


\section{Christopher Chávez, Reinventing the Latino Television Viewer: Language, Ideology, and Practice}

Lanham: Lexington Books, 2015, 180 pages

Emilie Cheyroux

\section{REFERENCES}

Christopher Chávez, Reinventing the Latino Television Viewer: Language, Ideology, and Practice, Lanham: Lexington Books, 2015, 180 pages

1 Christopher Chávez offers a detailed and incisive look at the evolution of television marketing practices towards the U.S. Latino viewers who, he argues, have always been "framed" (25) by the networks that need them to fit into their own definitions. This process has always involved forming a pseudo conglomeration of Latinos that does away with the differences that exist between them and recently, it has also led to the creation of the "New Latino" designation in audience categories. Chávez shows that television executives have used the young generation's bilingualism to justify the launch of new networks that offer English-language shows while still calling themselves Hispanic. Throughout the book, the author strives to highlight the stakes of such a shift, and sheds light on the fact that it's a construct supposed to attract the acculturated Latinos and turn them into profitable viewers. According to him (who interestingly has worked as an account executive in the general market television industry), the "mainstream" is entering the Hispanic space and might erase it. The example he uses as an introduction illustrates this argument: Fusion, a channel set up by agreement with $\mathrm{ABC}$ News and Univision Communications Inc. offers a wide range of topics with a Hispanic perspective. Chávez remarks that this fusion leans more towards an "erasure" (8) since the Hispanic cultural ties are used as a secondary focus. At the heart of this issue is the use of language that he discusses thoroughly as a commodity 
used subsequently to exclude and redefine the Latino viewer. Thus, this meticulous study, illustrated by numerous interviews with industry professionals, draws attention to the economic and cultural power assigned to Latinos in the United States.

The first chapters are necessary background since Chávez gives socio-historical details that enable the reader to understand the recent trends. He explains that there has been a constant movement of negotiation between the Hispanic audience and the television networks. Nevertheless, if the Latinos have pushed the US television landscape towards more diversity, the traditional conglomerates of all American viewers still control the movement. The last three chapters are much more efficient in developing Chávez' thoughts about the erasure of Hispanic cultural ties. He explains that there has always been a false opposition between English and Spanish that has led the networks to separate the mainstream and Hispanic spheres. But in spite of being marginalized, the Spanish-speaking viewers were still represented in the US television landscape. With the advent of the new English-language networks with the Hispanic sphere, Chávez dreads that these might be left behind. That's why he discusses questions of representation and democracy and explains why the possible disappearance of Spanish would be detrimental to Latinos.

In the first chapter, Chávez uses historical information in order to explore the creation of the first Hispanic media, starting with the press and the radio and ending with the emergence of a national television network. It is useful to understand that the media has contributed to the emergence of the pan-ethnic construct "Hispanic" and thus, to a first kind of erasure. Indeed, Univision (Spanish International Network from 1961 to 1986) started because its manager, Emilio Azcárraga Vidaurreta, was refused Mexican content by Anglo managers. Only when he launched his own network was the Hispanic audience constructed around linguistic and cultural unity. Throughout this chapter, and with of the help of Pierre Bourdieu's concept of fields and cultural capital, Chávez seeks to determine where the Hispanic audience is situated. From his perspective, the existence of Spanish-speaking networks has mainly enabled Latinos to create their own Spanish-language alternative channels that he deems essential as a counterhegemonic force. That is the reason why he wants to warn the reader of the implications coming with the arrival of new English-language Hispanic networks and with the recent buyouts and fusions that might also erase Hispanic content.

4 The "New Latino" is at the source of the shift Chávez discusses: young, bicultural, bilingual and at ease with social media, it is a perfect target for marketers. The strength of the second chapter is to enlighten the reader to the fact that in the postderegulation world, incredibly broad and precise methods are used to understand viewers. Chávez points out the absurdity of wanting to gather the smallest details about Latinos (statistics, study of the viewers' brain activity) while not recognizing their differences. He also takes every belief held by marketers about Latinos one by one and efficiently deconstructs them: where marketers use "corporate logic" (60), he adds sociological content. As a Latino himself, he accurately argues that believing that Latinos are all the same, and thinking that their identity is contradictory with being American are two common stereotypes held by society. The reality he defends is that of "multiple, intersectional identities" (69). He puts forward ideas that seem obvious for any person with a bicultural background but that marketers refuse to take into account: Hispanics are not just bicultural but "ambicultural" (69) and able to "pivot" (70) between their different cultural identities. They thus feel at ease with code 
switching and that's why Chávez makes language the core of his argument in the two subsequent chapters.

On television, Spanish has always been considered the language of "impurity" (89) and Chávez argues that mainstream networks have never managed to use it well (when it has been used) and it is usually replete with stereotypes. On television, Spanish is portrayed as a foreign accent the other characters and the audience can make fun of, as illustrated by the numerous mispronounced words and malapropisms used by Sofia Vergara's character on Modern Family (ABC, 2009- present). Admittedly, English has always been a source of power and English-speaking viewers have always been at the top of the audience hierarchy, which, in terms of market transactions, translates into mainstream networks buying the Hispanic ones, not the opposite. But with these buyouts come new linguistic issues and in the fourth chapter, Chávez finally illustrates his concept of erasure, analyzing all the new network channels and highlighting the contradictions of their approaches. Fusion is scrutinized again, as well as El Rey, the network launched by Robert Rodriguez, who is in the opinion of this reviewer the embodiment of the New Latino. Erasing consists in segmenting even further what Hispanics are and considering that they all correspond to the New Latino profile. This thinking allows marketers to state that while English has become the dominant language among Latinos, it should be the sole language of their programs. While Chávez is right to point out that bilingualism is not a new phenomenon, it can't be denied that the younger generations tend to prefer English, and it is thus almost inevitable to expect the television networks to exploit that. Nevertheless, the author rightfully explains that Hispanic culture runs the risk of becoming a flavor or an exotic artifact and that the generation who still prefers Spanish will not be served. The new networks are in fact more interested in attracting mainstream viewers. They thus only accept stories with a "crossover appeal"(122), in other words those accessible to the non-Hispanic audience, marginalizing even further the stories written by the Hispanic writers who do not fit into the new profile.

6 The issue of democracy comes naturally as an end of this book since Chávez reminds the reader that the advent of the new television networks does not entail better representation on screen and in society, as stereotypes continue to be widely used. He highlights a double perspective that explains why there is so much attention and economic interest directed towards Hispanics and why, at the same time, it does not guarantee further inclusion: the need to conquer markets and make profit from Latinos works hand in hand with the desire to suppress their forms of speech. The new networks are a consequence of both those endeavors and, according to Chávez, they advertise a false promise of inclusion that conceals a will to dominate the minority population even more. The problem Chávez raises is that the success of these new networks might lead the traditionally Spanish-language networks to pivot towards the mainstream and deliver content divested from its cultural heritage. Now, he postulates that only the Hispanic channels can act as a space of social advocacy. As Latinos continue to be considered foreigners within American society, however profitable, Chávez can only support the maintenance of the traditional Hispanic networks as they are. The assessment of the recent shift in television practices is thus rather pessimistic but Chávez ends on a positive note, expressing his hopes that the digital space will offer the alternative channels of expression that are essential to the civic participation of all Latinos. 
7 Chávez provides an insightful and enlightening analysis that is useful to anyone interested in Latino/a studies, media marketing strategies and their link to cultural and ideological issues. The last pages about the new digital perspectives are an original addition that could have been backed by a mention of the development of a network of Latino film festivals around the country. Indeed, these events program movies that deal with the issues of all Latinos, whether these are feature films from Latin American countries or documentaries about social issues affecting Latinos in the United States. At the periphery of Hollywood, these festivals fulfill the democratic role Chávez defends. Nevertheless, this book is an excellent read to understand the media's construction of a population that is shaping the US cultural, social and political landscape.

\section{AUTHORS}

\section{EMILIE CHEYROUX}

University Paris 3 Sorbonne Nouvelle 